\title{
Tensão e conciliação na política: o poder de veto e a questão do funcionalismo municipal (Capital Federal, 1892-1902)
}

\section{Marcelo de Souza Magalhães*}

Resumo: Neste artigo, busco refletir sobre o poder de veto do prefeito do Distrito Federal em relação aos projetos de lei aprovados pelos membros do Poder Legislativo municipal entre 1892 e 1902. A análise minuciosa do andamento das resoluções aprovadas pela casa legislativa, que foram ora sancionadas ou vetadas pelo prefeito, ora sancionadas pelo presidente da instituição, é uma forma de compreender melhor as tensões e conciliações na política municipal da capital federal. Um tema conflituoso na municipalidade, que colocava os poderes locais em pé de guerra, foi o do funcionalismo público, que receberá atenção especial ao longo do artigo.

Palavras-chave: história política carioca, funcionalismo municipal, poder de veto

Abstract: This article addresses the issue of the right of veto of the Federal District mayor concerning the bills passed in the Municipal Legislature between 1892 and 1902. A thorough analysis of the progress of the resolutions adopted by the legislative house, which were either sanctioned or vetoed by the mayor or sanctioned by the institution's president, allows us to better understand the tensions and reconciliations proper to the municipal politics in the federal capital. The issue that will receive special attention throughout the article is the topic of civil service; it was such a contentious issue to the municipality that put local authorities on warpath.

Keywords: Rio de Janeiro political history, municipal civil service, right of veto

De acordo com a Lei Orgânica de 1892', ao prefeito do Distrito Federal competia vetar ou sancionar as resoluções aprovadas pelo Conselho Municipal. O veto só poderia ser oposto a uma resolução do Legislativo caso ela estivesse em desacordo com as leis e com os regulamentos em vigor no distrito. Logo, consistia numa exposição dos motivos que levaram o prefeito a não sancionar determinada resolução do Conselho, visando convencer a instituição avaliadora do veto da pertinência de sua manutenção.

* Professor do Departamento de História da Universidade Federal do Estado do Rio de Janeiro - UNIRIO.

1 Lei $\mathrm{n} . \mathrm{o} 85,20$ de setembro de 1892. 
Inicialmente, de acordo com a Lei de 1892, ao Senado Federal coube o papel de instituição avaliadora dos vetos, decidindo, ao menos nesse caso, os embates entre Executivo e Legislativo municipais. No entanto, a Lei n. ${ }^{-493}$, de 19 de setembro de 1898, repartiu entre o Senado e o Conselho a atribuição de avaliar os vetos. Aos senadores cabia analisar as resoluções vetadas que podiam ir de encontro ao texto constitucional, às leis federais e aos direitos dos outros municípios ou estados. Por sua vez, os intendentes, atuais vereadores, ficaram responsáveis por avaliar as resoluções vetadas que podiam ser contrárias às leis municipais. A atuação dos intendentes não durou muito: cinco meses após a sanção da Lei n. 493 , entrou em vigor o Decreto n. ${ }^{\circ} 543^{2}$, que atribuiu novamente ao Senado o papel exclusivo de analisar os vetos opostos pelo prefeito da capital.

$O$ veto consiste num procedimento político estratégico para compreender a dinâmica das relações entre os poderes. Na política, existem ao menos duas possibilidades de ação de um chefe do Poder Executivo: a de fazer acontecer e, o seu inverso, a de fazer não acontecer. A primeira possibilidade diz respeito à capacidade de acionar, dirigir e interferir, de estar à frente de uma determinada ação. Quanto à segunda, trata de barrar uma ação feita por outros, como, por exemplo, pelos membros do Conselho Municipal. O poder do veto está no âmbito do fazer não acontecer. É um poder que interfere no ritmo da política, pois, ainda que muitas vezes não possa alterar o curso dos acontecimentos, pode modificar sua velocidade, adiando ou antecipando decisões. ${ }^{3}$

Se o prefeito era o único membro dos poderes municipais que podia fazer uso da ação de se opor ao veto, no caso da sanção de uma resolução do Conselho, o jogo político era mais delicado. O artigo 21 da Lei Orgânica de 1892 estabeleceu o prazo máximo de cinco dias para que o prefeito sancionasse ou vetasse qualquer resolução aprovada pela maioria dos intendentes. Findo o prazo, caso o prefeito não se posicionasse, cabia ao presidente do Conselho Municipal o ato da sanção. Isso implica dizer que o Poder Legislativo municipal, na figura de seu presidente, também possuía a atribuição de transformar em lei uma resolução aprovada pelos intendentes.

O objetivo deste artigo é fazer uma análise minuciosa — quantitativa e qualitativa — do andamento das resoluções aprovadas pela casa legislativa municipal, que foram ora sancionadas ou vetadas pelo prefeito do Distrito Federal, ora sancionadas pelo presidente da instituição. Além disso, dar atenção especial aos debates em torno de questões relativas ao funcionalismo municipal.

Entre 1892 e 1902, foram apresentadas e discutidas 1.872 resoluções pelos intendentes do Conselho Municipal. Resoluções que possuíam autoria individual (apresentadas por um intendente) ou coletiva (apresentadas por um grupo de intendentes ou pelas comissões permanentes da casa legislativa). Dos dois tipos de autoria, as resoluções apresentadas de forma coletiva eram as que tinham

2 Decreto n. 543 , de 23 de dezembro de 1898.

3 No campo da Ciência Política, os estudos que analisam os poderes legislativos do Executivo fazem uso de duas variáveis: poderes proativos e poderes reativos. Os primeiros são os que permitem ao chefe do Executivo ditar a agenda política a ser discutida e votada pelos membros do Poder Legislativo. Eles são constituídos pelo poder de decreto, de iniciativa exclusiva de matérias, de convocar referendos, e pelos poderes excepcionais de emergência. Os segundos estão relacionados basicamente ao poder de veto. No Brasil, existem atualmente dois tipos de poderes de veto: o total e o parcial. Este permite ao chefe do Executivo limpar as matérias de seu interesse das modificações feitas pelo Poder Legislativo. Já aquele é o que apresenta o menor nível de poder reativo, pois o chefe do Executivo só tem a opção de vetar por inteiro um projeto de lei aprovado pelo Legislativo. Como exemplo de trabalhos que utilizam essas variáveis, cf.: FIGUEIREDO, Argelina Cheibub e LIMONGI, Fernando. Executivo e Legislativo na nova ordem constitucional. Rio de Janeiro: Editora FGV, 2001; SANTOS, Fabiano (org.). O Poder Legislativo nos estados: diversidade e convergência. Rio de Janeiro: Editora FGV, 2001. 
maiores chances de obtenção de sucesso dentro dos trâmites legislativos. Nesse mesmo período, foram sancionadas 971 resoluções pelos prefeitos, bem como pelos presidentes do Conselho. Por outro lado, os prefeitos terminaram por vetar um total de 231 resoluções aprovadas pelos intendentes.

Logo, de um total de 1.202 projetos que tiveram suas tramitações iniciadas no Conselho Municipal, 2/3 foram aprovados pelos intendentes e chegaram às mãos dos prefeitos, para obterem sanção ou veto. 0 1/3 restante (570 resoluções) é constituído de projetos que apresentaram dois tipos de encaminhamentos: foram rejeitados pelos intendentes, quando das votações em plenário, ou ficaram pendentes de decisão, o que significa a suspensão da tramitação na casa legislativa. Desse modo, nos dez primeiros anos de organização político-administrativa nos moldes da Lei Orgânica de 1892, grande parte da produção legislativa do Conselho obteve a sanção ou o veto do prefeito. Algumas variáveis ajudam a compreender o poder de veto do prefeito do Distrito Federal.

\section{A rotatividade de um cargo: variável tempo de mandato dos prefeitos}

Entre 1892 e 1902, existiu uma significativa diferença na distribuição dos vetos e decretos entre os prefeitos do Distrito Federal, que se justifica, em grande parte, pela considerável variação no tempo de permanência no cargo.

\section{Quadro 1}

Período do mandato e meses de gestão dos prefeitos do Distrito Federal (1892-1902)

\begin{tabular}{|l|c|c|}
\hline \multicolumn{1}{|c|}{ Prefeito } & Mandato & $\begin{array}{c}\text { N.o de meses } \\
\text { de gestão** }\end{array}$ \\
\hline Candido Barata Ribeiro & $12 / 12 / 1892$ a 25/05/1893 & 5 \\
\hline Antônio Dias Ferreira (interino)* & $26 / 05 / 1893$ a 26/06/1893 & 1 \\
\hline Henrique Valadares & $27 / 06 / 1893$ a 31/12/1894 & 18 \\
\hline Francisco Furquim Werneck de Almeida & $01 / 01 / 1895$ a 15/11/1897 & 34 \\
\hline Joaquim José da Rosa (interino)* & $16 / 11 / 1897$ a 24/11/1897 & 0 \\
\hline Ubaldino do Amaral Fontoura & $25 / 11 / 1897$ a 15/11/1898 & 11 \\
\hline Luiz Van Revén (interino) & $17 / 11 / 1898$ a 30/12/1898 & 1 \\
\hline José Cesário de Faria Alvim & $31 / 12 / 1898$ a 31/01/1900 & 13 \\
\hline Honório Gurgel (interino)* & $05 / 05 / 1899$ a 23/05/1899 & 0 \\
\hline Antônio Coelho Rodrigues & $01 / 02 / 1900$ a 06/09/1900 & 7 \\
\hline João Felipe Pereira & $06 / 09 / 1900$ a 10/10/1901 & 13 \\
\hline Joaquim Xavier da Silveira Junior & $11 / 10 / 1901$ a 27/09/1902 & 11 \\
\hline Carlos Leite Ribeiro (interino)* & $27 / 10 / 1902$ a 29/12/1902 & 2 \\
\hline
\end{tabular}

Fonte: REIS, José de Oliveira. O Rio de Janeiro e seus prefeitos. Rio de Janeiro: Prefeitura da cidade do Rio de Janeiro, 1977; CARVALHO, Carlos Delgado de. História da cidade do Rio de Janeiro. Rio de Janeiro: Secretaria Municipal de Cultura, Departamento Geral de Documentação e Informação, 1990.

* presidente do Conselho Municipal / ** foram levados em consideração somente os meses completos

Os resultados do Quadro 1 mostram que os anos de 1892 a 1902 foram de imensa instabilidade política no âmbito dos poderes municipais, com alta rotatividade de prefeitos. Nenhum permaneceu nesse cargo por quatro anos, tempo de mandato definido pela Lei Orgânica de 1892. Na verdade, esse prazo foi alvo de modificação 
por parte do Congresso Nacional. Passados seis anos de vigência da Lei, o artigo 2.. do Decreto n. .543 , de 23 de dezembro de 1898 , suprimiu o tempo de mandato, definindo que o prefeito nomeado continuaria desempenhando suas funções enquanto bem servir. Modificação que consistiu em uma clara restrição da liberdade de atuação da pessoa nomeada para estar à frente do cargo de prefeito.

A indefinição do tempo, condicionada à avaliação subjetiva do prefeito pelo crivo do bem servir, provavelmente tinha a intenção de aproximar a atuação do chefe do Executivo municipal dos interesses de quem lhe delegou o poder, o presidente da República. A partir do Decreto n. ${ }^{\circ} 543$, - sancionado por Campos Sales (15/11/1898 a 15/11/1902), presidente que buscou intervir de forma muito decisiva no jogo político carioca - ficou superado o constrangimento a que teria de passar o chefe do Executivo federal devido ao fato de exonerar um prefeito antes do término de seu mandato.

A supressão do tempo de mandato do prefeito ajuda a relativizar a interpretação de sua atuação como um interventor federal, ao menos entre 1892 e 1902. Tal interpretação valoriza muito fortemente o fato de o poder do prefeito ser delegado pelo presidente da República, pressupondo que a atuação do primeiro é orquestrada de acordo com os interesses do segundo. Isto é, a prefeitura seria quase um órgão do aparelho administrativo da União. Contudo, tal suposição fica abalada quando se pensa nas razões políticas que produziram o Decreto n. 543 . Isso porque esse decreto mostra claramente o quanto, nos anos iniciais da Prefeitura do Distrito Federal, era pouco provável a existência de uma grande sincronia entre os dois executivos. Do mesmo modo, não teria sentido o investimento feito na modificação legal do tempo de mandato, caso o prefeito não estivesse incomodando alguém. O bem servir é seguido certamente de uma interrogação: a quem? No caso, ao Executivo federal, que tentava, com o controle do tempo de mandato, obter uma efetiva aliança com o prefeito.

Assim, entre 1892 e 1902, o cargo de prefeito foi ocupado por 14 pessoas, o que evidencia sua fantástica rotatividade. Destes, seis assumiram interinamente, sendo cinco presidentes do Conselho - Alfredo Augusto Vieira Barcellos, Antonio Dias Ferreira, Joaquim José da Rosa, Honório Gurgel e Carlos Leite Ribeiro — e um nomeado pelo presidente da República — Luiz Van Erven. ${ }^{4}$

De acordo com a Lei Orgânica de 1892, em caso de vacância do cargo, cabia ao presidente do Conselho assumir interinamente a chefia do Executivo local. Isso indica que o presidente do Legislativo era detentor de um considerável poder, uma vez que, entre outras atribuições, desempenhava o papel de substituto oficial do prefeito.

Somente em 1902, num momento de grande restrição das atribuições do Conselho Municipal dentro do campo político-institucional carioca, é que o seu presidente perdeu o direito de substituir o prefeito, o que ocorre com a sanção da Lei $\mathrm{n}$. 939 , de 29 de dezembro.

Dos oito prefeitos efetivos, apenas dois permaneceram no cargo em torno de seis meses: Candido Barata Ribeiro (cinco meses) e Antonio Coelho Rodrigues (sete meses), sendo o primeiro o único nomeado pelo presidente da República

4 Nasceu em 1857, na então Província do Rio de Janeiro, e faleceu em 1927. Engenheiro formado, foi diretor da Repartição de Águas e Esgotos do Rio de Janeiro antes de assumir interinamente a Prefeitura do Distrito Federal. As referências biográficas dos prefeitos do Distrito Federal foram extraídas, sobretudo, de: PINTO, Surama Conde Sá. Elites políticas e o jogo do poder na cidade do Rio de Janeiro (1909-1922). Tese (Doutorado em História Social). Rio de Janeiro: PPGHIS-UFRJ, 2002. 
que teve seu nome rejeitado pelos membros do Senado Federal. ${ }^{5}$

A soma do tempo de mandato dos demais prefeitos efetivos (Henrique Valadares, Francisco Furquim Werneck de Almeida, Ubaldino do Amaral Fontoura, José Cesário de Faria Alvim, João Felipe Pereira e Joaquim Xavier da Silveira Junior) equivale a pouco mais de oito anos à frente da prefeitura. Em conjunto, portanto, são esses seis prefeitos que governam por $80 \%$ da década estudada.

Mas esse resultado ainda pode ser matizado, caso se leve em conta a modificação na política do governo federal para a capital da República, ocorrida após o atentado à vida do presidente Prudente de Morais, em 1897. O atentado provocou uma tentativa de enquadrar a política na capital, reduzindo a ingerência das forças locais nos poderes municipais, o que foi levado às últimas consequências na gestão de Campos Sales. ${ }^{6}$

O marco produzido pelo atentado reflete-se claramente no tempo de permanência no cargo. Antes do atentado, Henrique Valadares (18 meses) - nomeado por Floriano Peixoto - e Francisco Furquim Werneck de Almeida (34 meses) — nomeado por Prudente de Morais - permaneceram, em conjunto, pouco mais de quatro anos (52 meses) à frente da prefeitura. ${ }^{7}$ Após o atentado, já na presidência de Campos Sales, em apenas quatro anos, passaram pela prefeitura sete pessoas, dentre as quais cinco nomeadas: Luiz Van Erven (1 mês), José Cesário de Faria Alvim (13 meses), Antonio Coelho Rodrigues (7 meses), João Felipe Pereira (13 meses) e Joaquim Xavier da Silveira Junior (11 meses).

A rotatividade no cargo foi sem dúvida mais intensa no governo Campos Sales, o que aponta para tensões entre o Executivo municipal e o Conselho e entre aquele e o Executivo federal. Tensões que possuíam, ao menos, uma explicação. Os anos iniciais da República foram de profunda aprendizagem política. Neles, antigas e novas forças políticas passaram a atuar em instituições que acabavam de ser criadas, o que implicava, dentre outras coisas, a invenção de tradições diferentes do fazer política: outros vocabulário, cargos, rituais, formas de se relacionar etc. ${ }^{8}$

É justamente nesse momento que, com a Lei Orgânica de 1892, se criou a figura do prefeito, até então inédita no âmbito dos poderes que administravam a cidade. Vale assinalar que, no período colonial, o governo da cidade era feito, sobretudo, pelo Senado da Câmara e, no período imperial, pela Câmara Municipal. Portanto, até 1892, a cidade do Rio de Janeiro possuía apenas instituições colegiadas como responsáveis por sua administração. ${ }^{9}$

Criada a função de prefeito, ela ficou muito dependente das decisões toma-

5 ara acompanhar o processo de rejeição da indicação de Barata Ribeiro, cf.: BASTOS, Ana Marta Rodrigues. $O$ Conselho de Intendência Municipal: autonomia e instabilidade (1889-1892). Rio de Janeiro: CEH/FCRB, 1984, mimeo. WEID, Elisabeth von der. O prefeito como intermediário entre o poder federal e o poder municipal na Capital da República. Rio de Janeiro: CEH-FCRB, 1984, mimeo.

6 Cf.: FREIRE, Américo. Uma capital para a República: poder federal e forças políticas locais no Rio de Janeiro na virada para o século XX. Rio de Janeiro: Revan, 2000, em especial, o capítulo 3.

7 O que equivale a $40 \%$ da década estudada e/ou $52 \%$ do tempo de mandato dos seis prefeitos que mais estiveram no cargo entre 1892 e 1902.

8 Para se ter uma noção das disputas entre projetos políticos nos primeiros anos republicanos, cf.: LESSA, Renato. A invenção republicana: Campos Sales, as bases e a decadência da Primeira República brasileira. São Paulo: Editora Vértice, 1988; GOMES, Angela de Castro. A invenção do trabalhismo. São Paulo: Editora Vértice, Rio de Janeiro: IUPERJ, 1988, em especial, a 1. a parte. CARVALHO, José Murilo de. A formação das almas: o imaginário da República no Brasil. São Paulo: Companhia das Letras, 1990.

9 É importante ressaltar que o tipo de organização administrativa que teria o município não foi definido na Constituição da República de 1891. Logo, alguns municípios, como o Distrito Federal, criaram o cargo de prefeito, separando os poderes Executivo e Legislativo; outros municípios mantiveram um tipo de organização próximo ao das Câmaras Municipais do Império, sendo o presidente da Câmara um cargo com responsabilidades mais administrativas. 
das pelos membros do Conselho, pelo fato de a Lei Orgânica ter definido nada menos do que 37 atribuições ${ }^{10}$ para a casa legislativa. Ou seja, para governar, qualquer prefeito nomeado tinha que, minimamente, tentar conseguir o apoio de boa parte dos intendentes, o que por vezes, pode ter implicado ir de encontro aos interesses de quem lhe delegou o poder, o Executivo federal.

\section{Os sentidos do poder de veto}

\section{Os vetos: quantos são?}

O tempo de permanência no cargo de Prefeito do Distrito Federal, entre 1892 e 1902, permite compreender, em parte, a significativa diferença dos números absolutos presentes na Tabela 1.

Tabela 1

Distribuição de vetos e de decretos por mandato de Prefeito do Distrito Federal (1892-1902)

\begin{tabular}{|c|c|c|c|c|}
\hline Prefeito & $\begin{array}{l}\text { N.o de } \\
\text { vetos }\end{array}$ & $\begin{array}{c}\text { N. }{ }^{\circ} \text { de } \\
\text { decretos }\end{array}$ & Total & $\%$ veto \\
\hline Candido Barata Ribeiro & 15 & 42 & 57 & 26,3 \\
\hline Antônio Dias Ferreira (interino)* & 0 & 5 & 5 & 0,0 \\
\hline Henrique Valadares & 12 & 93 & 105 & 11,4 \\
\hline Francisco Furquim Werneck de Almeida & 38 & 341 & 379 & 10,0 \\
\hline Joaquim José da Rosa (interino)* & 1 & 12 & 13 & 7,7 \\
\hline Ubaldino do Amaral Fontoura & 44 & 161 & 205 & 21,5 \\
\hline Luiz Van Revén (interino) & 13 & 18 & 31 & 41,9 \\
\hline José Cesário de Faria Alvim & 55 & 72 & 127 & 43,3 \\
\hline Honório Gurgel (interino)* & 0 & 8 & 8 & 0,0 \\
\hline Antônio Coelho Rodrigues & 11 & 30 & 41 & 26,8 \\
\hline João Felipe Pereira & 21 & 56 & 77 & 27,3 \\
\hline Joaquim Xavier da Silveira Junior & 16 & 77 & 93 & 17,2 \\
\hline Carlos Leite Ribeiro (interino)* & 5 & 56 & 61 & 8,2 \\
\hline $\begin{array}{ll}\text { TOTAL } \\
\end{array}$ & 231 & 971 & 1202 & \\
\hline
\end{tabular}

Fonte: Boletim da Intendência Municipal do Distrito Federal (1892-1902)

* presidente do Conselho Municipal

Uma das variáveis que levou o prefeito Francisco Furquim Werneck de Almeida a apresentar o maior número absoluto resultante da soma dos vetos com os decretos (379) foi a de ter estado à frente da prefeitura por mais tempo, isto é, 34 meses. O mesmo pode ser dito em relação aos prefeitos interinos, que, pelo fato de permanecerem, em média, um mês à frente da prefeitura, apresentaram os menores números absolutos.

Porém, o tempo de permanência no cargo de prefeito não é a única explicação da diferença. Outra variável que deve ser levada em consideração é a do volume da produção legislativa, do número de resoluções que eram aprovadas no Conselho e que chegavam ao prefeito para sanção ou veto. Tal número variou muito de acordo com as conjunturas políticas da década.

10 Para as atribuições, cf.: Art. 15, da Lei n.ㅇ 85, de 20 de setembro de 1892. 
Dos seis prefeitos que, juntos, permaneceram o total de oito anos à frente do Executivo, tirando a média por mês das resoluções do Conselho vetadas e sancionadas, temos: Ubaldino do Amaral Fontoura (18,63 resoluções/mês), Francisco Furquim Werneck de Almeida (11,14), José Cesário de Faria Alvim $(9,76)$, Joaquim Xavier da Silveira Junior $(8,45)$, João Felipe Pereira $(5,92)$ e, por fim, Henrique Valadares (5,83).

A média ajuda a perceber o volume da produção legislativa, dissociando-o da variável tempo de permanência no cargo de prefeito. Apenas como exemplo, ela permite chegar ao seguinte resultado: o prefeito Ubaldino do Amaral, em 11 meses de gestão, vetou e sancionou três vezes mais, por mês $(18,63)$, do que o prefeito Henrique Valadares $(5,83)$, que permaneceu no cargo durante um ano e meio.

Feitas as ressalvas quanto à diferença existente entre os números absolutos, vamos à análise dos resultados da Tabela 1. A hipótese é a de que o percentual de vetos interpostos por cada prefeito seja um indício do tipo de relação construída com os membros da casa legislativa municipal. Logo, quanto maior o percentual, maior é a possibilidade de que a gestão do prefeito tenha sido caracterizada por uma relação conflituosa com os intendentes; sendo o inverso também verdadeiro: quanto menor o percentual, mais o prefeito teria uma relação amistosa ou conciliatória com os intendentes.

Os prefeitos Henrique Valadares e Furquim Werneck de Almeida, ao longo de pouco mais de quatro anos de mandato, vetaram por volta de $10 \%$ das resoluções aprovadas pelo legislativo municipal. Ambas as gestões possuíram um percentual extremamente pequeno de vetos e um significativo número de resoluções sancionadas, transformando-se em decretos ( 93 e 341, respectivamente). Para se ter uma ideia desse volume, basta verificar que os dois prefeitos juntos sancionaram quase 45\% das resoluções apresentadas entre 1892 e 1902.

O percentual de vetos interpostos por Valadares e Almeida está, inclusive, próximo ao dos prefeitos interinos, sempre abaixo dos 10\% - Joaquim José da Rosa (7,7\%) e Carlos Leite Ribeiro (8,2\%). Tal proximidade é um indício de que esses prefeitos efetivos procuraram de alguma forma construir administrações capazes de dialogar com os membros do Conselho, uma vez que, sem isso, seria impossível tal resultado. Como vimos, de acordo com a Lei Orgânica de 1892, a origem dos prefeitos interinos, excetuando Luiz Van Erven, era a própria casa legislativa. O fato de pertencerem ao Conselho, provavelmente explica o baixo percentual de vetos enquanto estiveram à frente da prefeitura.

Outro indício que corrobora a argumentação de terem sido as gestões de Valadares e Almeida as de maior diálogo com os intendentes, no sentido de conciliar interesses diversos, está relacionado com o número absoluto de vetos. O total de vetos dos quatro anos de administração desses prefeitos - em número de 50 - é próximo aos vetos interpostos em 11 meses de gestão de Ubaldino do Amaral (44 vetos) e em 13 meses de gestão de José Cesário de Faria Alvim (55 vetos). Dito de outra forma, ao longo da década estudada, os quatro anos de Valadares e Almeida correspondem a quase $22 \%$ dos vetos totais e os dois anos de Fontoura e Alvim correspondem, praticamente, ao dobro: $43 \%$ dos vetos totais.

O quarto prefeito efetivo, Ubaldino do Amaral Fontoura, que substituiu Werneck de Almeida, vetou, percentualmente, um pouco mais que o dobro (21,5\%) dos vetos interpostos pela gestão anterior. Como veremos adiante, esses dois prefeitos vivenciaram o início do processo de enquadramento político da capital, após o atentado fracassado contra a vida de Prudente de Morais. Ambos foram nomeados por esse presidente - Almeida antes e Amaral depois do referido atentado, o que torna suas administrações bastante interessantes. 
O fato de vetar um pouco mais de $1 / 5$ das resoluções aprovadas pelos intendentes indica que a atuação de Ubaldino do Amaral à frente da prefeitura esteve longe de ser conciliatória em relação ao Conselho, ao menos se compararmos com as gestões anteriores de Valadares e Almeida, em que os vetos ficaram próximos de 1/10 das resoluções aprovadas. No mínimo, pode-se dizer que, na gestão de Ubaldino do Amaral, ocorreu um aumento de tensão na relação com o Conselho, tornando-se o diálogo entre Executivo e Legislativo municipal mais difícil.

Com José Cesário de Faria Alvim, quinto prefeito efetivo e o primeiro nomeado por Campos Sales, mais uma vez, o percentual total de vetos interpostos $(43,3 \%)$ foi o dobro do da gestão anterior, de Ubaldino do Amaral, que já era alto. Em números absolutos, isso equivale dizer que Alvim vetou 55 e sancionou 72 resoluções aprovadas pelo Conselho.

Comparando a gestão de Alvim com as de Valadares e Almeida, a diferença percentual de vetos passa a ser brutal, chegando a um aumento de $400 \%$. Isto é, o prefeito Cesário Alvim, em pouco mais de 1 ano de administração, vetou 4 vezes mais resoluções que Valadares e Almeida em 52 meses de administração. Esse aumento significativo não deixa dúvidas de que, ao menos no momento de vetar, a relação entre Cesário Alvim e os membros do Conselho foi conflituosa.

Os dados analisados até aqui possibilitam caracterizar a gestão de cada prefeito, no que tange à relação com a casa legislativa municipal, tomando-a como um todo, sem nuances. Isto é, pela menor quantidade de vetos, infere-se que as gestões de Valadares e Almeida mantiveram relações amistosas com o Conselho. O inverso ocorreu no caso de gestões como as de Fontoura e Alvim, pelo fato de possuírem maior quantidade de vetos.

Uma forma de sofisticar essa visão das administrações dos prefeitos quanto à relação que mantinham com o Conselho, é a de distribuir os vetos ao longo de cada gestão. Os resultados presentes no Quadro 2 permitem perceber quais são os momentos, no interior das gestões, em que ocorreram os vetos, o que situa, com precisão, o aumento do conflito com a instituição legislativa.

\section{Quadro 2}

Distribuição dos vetos por mês (prefeitos efetivos do Distrito Federal, 1892-1902)

\begin{tabular}{|l|c|c|c|c|}
\hline \multicolumn{1}{|c|}{ Prefeito } & Mandato & $\begin{array}{c}\text { Período total de } \\
\text { gestão }\end{array}$ & $\begin{array}{c}\text { Meses } \\
\text { de gestão }\end{array}$ & $\begin{array}{c}\text { Quantidade } \\
\text { de vetos }\end{array}$ \\
\hline Henrique Valadares & 27/06/1893 & 18 meses & $11 / 1893$ & 1 \\
\cline { 4 - 5 } & a 31/12/1894 & & $01 / 1894$ & 3 \\
\cline { 4 - 5 } & & $02 / 1894$ & 1 \\
\cline { 4 - 5 } & & $04 / 1894$ & 1 \\
\cline { 4 - 5 } & & $05 / 1894$ & 2 \\
\cline { 4 - 5 } & & $06 / 1894$ & 1 \\
\cline { 4 - 5 } & & $10 / 1894$ & 2 \\
\hline TOTAL & & $11 / 1894$ & 1 \\
\cline { 3 - 5 } & & 18 meses & 12 \\
\hline
\end{tabular}


Quadro 2

Distribuição dos vetos por mês (prefeitos efetivos do Distrito Federal, 1892-1902)

\begin{tabular}{|c|c|c|c|c|}
\hline Prefeito & Mandato & $\begin{array}{l}\text { Período total de } \\
\text { gestão }\end{array}$ & $\begin{array}{c}\text { Meses } \\
\text { de gestão }\end{array}$ & $\begin{array}{c}\text { Quantidade } \\
\text { de vetos }\end{array}$ \\
\hline \multirow{19}{*}{$\begin{array}{l}\text { Francisco Furquim } \\
\text { Werneck de Almeida }\end{array}$} & \multirow{19}{*}{$\begin{array}{c}01 / 01 / 1895 a \\
15 / 11 / 1897\end{array}$} & \multirow[t]{19}{*}{34 meses } & $01 / 1895$ & 1 \\
\hline & & & $05 / 1895$ & 1 \\
\hline & & & $07 / 1895$ & 1 \\
\hline & & & $08 / 1895$ & 2 \\
\hline & & & $09 / 1895$ & 2 \\
\hline & & & $10 / 1895$ & 4 \\
\hline & & & $11 / 1895$ & 4 \\
\hline & & & $02 / 1896$ & 1 \\
\hline & & & $04 / 1896$ & 3 \\
\hline & & & $05 / 1896$ & 3 \\
\hline & & & $08 / 1896$ & 2 \\
\hline & & & $10 / 1896$ & 1 \\
\hline & & & $11 / 1896$ & 1 \\
\hline & & & $12 / 1896$ & 1 \\
\hline & & & $04 / 1897$ & 2 \\
\hline & & & $05 / 1897$ & 4 \\
\hline & & & $09 / 1897$ & 1 \\
\hline & & & $10 / 1897$ & 2 \\
\hline & & & $11 / 1897$ & 2 \\
\hline \multicolumn{3}{|l|}{ TOTAL } & 34 meses & 38 \\
\hline \multirow{8}{*}{$\begin{array}{l}\text { Ubaldino do Amaral } \\
\text { Fontoura }\end{array}$} & \multirow{8}{*}{$\begin{array}{l}25 / 11 / 1897 \text { a } \\
15 / 11 / 1898\end{array}$} & \multirow[t]{8}{*}{11 meses } & $11 / 1897$ & 2 \\
\hline & & & $12 / 1897$ & 4 \\
\hline & & & $01 / 1898$ & 1 \\
\hline & & & $04 / 1898$ & 2 \\
\hline & & & $05 / 1898$ & 18 \\
\hline & & & $09 / 1898$ & 1 \\
\hline & & & $10 / 1898$ & 6 \\
\hline & & & $11 / 1898$ & 10 \\
\hline \multicolumn{3}{|l|}{ TOTAL } & 11 meses & 44 \\
\hline \multirow{9}{*}{$\begin{array}{l}\text { José Cesário de } \\
\text { Faria Alvim }\end{array}$} & \multirow{9}{*}{$\begin{array}{l}31 / 12 / 1898 \text { a } \\
31 / 01 / 1900\end{array}$} & \multirow[t]{9}{*}{13 meses } & $11 / 1898$ & 1 \\
\hline & & & $01 / 1899$ & 15 \\
\hline & & & $03 / 1899$ & 2 \\
\hline & & & $04 / 1899$ & 8 \\
\hline & & & $06 / 1899$ & 5 \\
\hline & & & $09 / 1899$ & 4 \\
\hline & & & $10 / 1899$ & 12 \\
\hline & & & $11 / 1899$ & 2 \\
\hline & & & $12 / 1899$ & 6 \\
\hline \multicolumn{3}{|l|}{ TOTAL } & 13 meses & 55 \\
\hline \multirow[t]{8}{*}{ João Felipe Pereira } & \multirow{8}{*}{$\begin{array}{l}\text { 06/09/1900 } \\
\text { a 10/10/1901 }\end{array}$} & \multirow[t]{8}{*}{13 meses } & $09 / 1900$ & 3 \\
\hline & & & $10 / 1900$ & 8 \\
\hline & & & $11 / 1900$ & 1 \\
\hline & & & $12 / 1900$ & 1 \\
\hline & & & $04 / 1901$ & 4 \\
\hline & & & $05 / 1901$ & 2 \\
\hline & & & 09/1901 & 1 \\
\hline & & & $10 / 1901$ & 1 \\
\hline \multicolumn{3}{|l|}{ TOTAL } & 13 meses & 21 \\
\hline
\end{tabular}




\section{Quadro 2}

\section{Distribuição dos vetos por mês (prefeitos efetivos do Distrito}

Federal, 1892-1902)

\begin{tabular}{|c|c|c|c|c|}
\hline Prefeito & Mandato & $\begin{array}{c}\text { Período total de } \\
\text { gestão }\end{array}$ & $\begin{array}{c}\text { Meses } \\
\text { de gestão }\end{array}$ & $\begin{array}{c}\text { Quantidade } \\
\text { de vetos }\end{array}$ \\
\hline \multirow{9}{*}{$\begin{array}{l}\text { Joaquim Xavier da } \\
\text { Silveira Junior }\end{array}$} & \multirow{9}{*}{$\begin{array}{l}11 / 10 / 1901 \mathrm{a} \\
27 / 09 / 1902\end{array}$} & \multirow[t]{9}{*}{11 meses } & $10 / 1901$ & 2 \\
\hline & & & $11 / 1901$ & 4 \\
\hline & & & $12 / 1901$ & 2 \\
\hline & & & $01 / 1902$ & 1 \\
\hline & & & $02 / 1902$ & 1 \\
\hline & & & $03 / 1902$ & 3 \\
\hline & & & $04 / 1902$ & 1 \\
\hline & & & $05 / 1902$ & 1 \\
\hline & & & 09/1902 & 1 \\
\hline \multicolumn{3}{|l|}{ TOTAL } & 11 meses & 16 \\
\hline
\end{tabular}

Fonte: Boletim da Intendência Municipal do Distrito Federal (1892-1902).

* foram contados apenas os meses completos

No caso das gestões de Henrique Valadares e Werneck de Almeida, a distribuição de vetos por mês não acrescenta grande novidade. Ela apenas corrobora a argumentação de que foram prefeitos que buscaram construir boas relações com o Conselho. Ambas as gestões são desprovidas de momentos de concentração no número de vetos. Inclusive, o primeiro veto de Valadares ocorreu somente no seu quinto mês de gestão (novembro de 1893), sinalizando um início de mandato com relações bastante tranquilas com os intendentes.

Diferente das anteriores, na gestão de Ubaldino do Amaral, os meses de maio e novembro de 1898 foram de picos. Nesses dois meses estão concentrados $63,62 \%$ dos vetos interpostos pelo prefeito. Em novembro, todos os vetos ocorreram na primeira quinzena, pelo fato de o prefeito ter deixado o cargo no dia 15. A concentração de vetos no final da gestão permite pensar que sua saída da prefeitura ocorreu num clima de embate com os membros da casa legislativa. Aprofundando a análise, vi que as resoluções que beneficiavam de alguma forma o funcionalismo municipal foram o alvo principal dos vetos de Ubaldino do Amaral. Em maio, seis das 18 resoluções vetadas e, em novembro, cinco das dez resoluções, diziam respeito a tal temática (33,33\% e 50\%, respectivamente). Mas pode-se dizer que as resoluções relativas ao funcionalismo ocuparam o primeiro lugar dos vetos, ao longo de toda a gestão de Ubaldino do Amaral: 16 das 44 resoluções vetadas, ou 36,36\%.

As medidas que beneficiavam o funcionalismo municipal possuíam um largo espectro: concessão de licença, reintegração no cargo, aposentadoria, contagem de tempo de serviço etc. Apenas como exemplo do tipo de questão em que prefeito e intendentes se envolviam, em 9 de maio de 1898, Ubaldino do Amaral vetou a resolução que concedia licença, por seis meses, à professora adjunta Obdulia Carolina Vasconcellos de Loureiro, com todos os vencimentos. ${ }^{11}$

Para além das demandas do funcionalismo, os vetos interpostos em maio e novembro de 1898 versavam sobre assuntos como: concessões diversas, ensino municipal, intervenção em logradouro público, patrimônio municipal, repartições públicas, transporte de bondes e posturas municipais. Algo, em princípio, mais substancial para a vida da cidade do que questões que incidiam sobre o destino dos servidores públicos.

11 Boletim da Intendência Municipal, de abril a junho de 1898, p. 36. 
Na administração do prefeito José Cesário de Faria Alvim também houve momentos de concentração significativa de vetos, sinalizando um acirramento da relação com os membros do Conselho. Acirramento que ocorre logo em seu primeiro mês à frente da prefeitura, quando vetou 15 resoluções aprovadas pelos intendentes (janeiro de 1899). Abril e outubro deste ano também foram meses de picos de vetos: 8 e 12, respectivamente. Em apenas três dos 13 meses de sua gestão, estão concentrados $63,62 \%$ dos vetos.

Durante o mês de janeiro, repetiu-se o padrão de concentração em um determinado assunto, tal como ocorreu na gestão de Ubaldino do Amaral, sendo que 6 das 15 (40\%) resoluções vetadas eram relativas a medidas que beneficiavam o funcionalismo. O mesmo não se verifica em abril e outubro, quando os vetos interpostos por Cesário Alvim possuíam temas diversos. As resoluções vetadas diziam respeito à mudança de denominação de ruas, ao calçamento e ao prolongamento de logradouro público; à revisão no contrato assinado com empresa de bonde; à prorrogação no pagamento de impostos; à abertura de crédito extraordinário no orçamento; a concessões de licença, de reintegração, de indenização e de equiparação de vencimentos do funcionalismo municipal etc.

O fato de os meses de alta concentração de vetos não serem dominados por um assunto específico é indício de que a gestão de Cesário Alvim apresentava um padrão de conflito difuso com a casa legislativa municipal, ou seja, que não havia apenas uma única e grande questão, como no caso das resoluções voltadas para beneficiar o funcionalismo, como ocorreu com Ubaldino do Amaral. A existência de um padrão difuso de vetos pode significar um conflito exacerbado com o Conselho, ao menos no que diz respeito à produção legislativa, em que qualquer resolução podia ser alvo de veto do prefeito.

Entretanto, a existência e predominância de um assunto específico, como elemento que estimula uma alta concentração de vetos, voltou à cena na gestão de João Felipe Pereira. No segundo mês à frente do Executivo (outubro de 1900), concentram-se 38,09\% das resoluções vetadas por esse prefeito, sendo que quatro dos oito vetos diziam respeito à questão do transporte de bonde. Em 4 de outubro de 1900, por exemplo, ele vetou a resolução que autorizava renovar o contrato celebrado em 1.. de julho de 1899 com a Companhia de São Cristóvão. ${ }^{12}$ Dois dias depois, em 6 de outubro, vetou duas resoluções que concediam autorização para construir linhas de bonde. ${ }^{13}$

Apesar da questão do transporte de bonde ter sido geradora de um aumento de tensão na relação entre o prefeito e os intendentes, ao longo da gestão de Felipe Pereira ela não se constituiu em um ponto constante de conflito. Em seus 13 meses de administração, excetuando outubro de 1900, as resoluções vetadas eram relativas a assuntos diversos, tais como: o abastecimento de carne, as concessões públicas, o funcionalismo municipal, o orçamento, as posturas municipais, as subvenções públicas etc.

O último prefeito efetivo nomeado por Campos Sales, Joaquim Xavier da Silveira Junior, contrariando o padrão da gestão de seus colegas anteriores, não possuiu, ao longo de seus onze meses de mandato, nenhuma alta concentração de vetos. Apesar de não existir um mês com pico de vetos, a administração de Xavier da Silveira Junior, do mesmo modo que a de Ubaldino do Amaral, também apresentou uma concentração em torno de medidas que beneficiavam o funcionalismo municipal, perfazendo o total de seis das 16 resoluções vetadas, ou $37,5 \%$.

12 Idem, de abril a junho de 1899, p. 83-86.

13 Cf.: Ibidem, p. 89-90 e p. 87-89. 
Eram resoluções que concediam a aposentadoria com todos os vencimentos, o aproveitamento de uma pessoa num determinado cargo, a transferência de funcionários, a reintegração e a contagem de tempo de serviço.

Os dados analisados até aqui reforçam o argumento de que as gestões de Valadares e de Almeida buscaram construir relações senão amistosas, ao menos, pouco conflituosas com o Conselho, considerando o menor uso do poder de veto. No caso dos prefeitos posteriores, é possível perceber as nuances de cada gestão. Nenhuma dessas administrações pode ser caracterizada como tendo mantido sempre uma relação de conflito com a casa legislativa municipal. Ao longo de cada gestão, o que ocorreu foram períodos de melhores ou piores relações com os intendentes.

\section{Os vetos: o que se veta?}

Outra variável importante para compor o quadro das relações existentes entre os prefeitos e os intendentes do Conselho é o da natureza das matérias vetadas. Ao menos para os meses de alta concentração de vetos, já tivemos uma prévia dos resultados dessa variável. Resta agora analisar a década estudada para compreender melhor o tipo de matéria que era alvo das disputas políticas entre Executivo e Legislativo municipal. A Tabela 2 constrói uma panorâmica das matérias, a partir do exercício do veto do prefeito.

Tabela 2

Natureza das matérias vetadas pelos prefeitos do Distrito Federal (1893-1902)

\begin{tabular}{|c|c|c|}
\hline Matérias & Total & $\%$ \\
\hline Funcionalismo Municipal & 65 & 28,14 \\
\hline Obras Públicas & 29 & 12,55 \\
\hline Posturas Municipais & 27 & 11,69 \\
\hline Transporte Público & 26 & 11,26 \\
\hline Ensino Municipal & 14 & 6,06 \\
\hline Impostos & 12 & 5,19 \\
\hline Orçamento & 8 & 3,46 \\
\hline Abastecimento & 6 & 2,60 \\
\hline Patrimônio Municipal & 6 & 2,60 \\
\hline Administração Pública & 5 & 2,16 \\
\hline Loteria & 5 & 2,16 \\
\hline Comemorações e Homenagens & 3 & 1,30 \\
\hline Iluminação Pública & 3 & 1,30 \\
\hline Limpeza Urbana & 3 & 1,30 \\
\hline Desconhecidas e Outras & 19 & 8,23 \\
\hline TOTAL & 231 & 100,00 \\
\hline
\end{tabular}

Fonte: Boletim da Intendência Municipal do Distrito Federal (1892-1902)

Pelos resultados, concluo que as medidas que envolviam o funcionalismo municipal ocuparam o primeiro lugar nas resoluções vetadas por todos os prefeitos entre 1893 e 1902. Das 231 resoluções vetadas, nada menos que 65 versavam sobre o funcionalismo, ou seja, cerca de 1/4. Para um período posterior, que vai de 1909 a 1922, Surama Conde de Sá Pinto também constatou a prevalência das medidas que 
incidiam sobre o funcionalismo público nos vetos interpostos pelos prefeitos. De 347 resoluções vetadas, 244 tratavam do tema, isto é, $60 \% .^{14}$ Isso equivale a dizer que os prefeitos, de 1892 até 1922, fizeram do tema funcionalismo um dos maiores pontos de discórdia da administração da capital federal. O que tem significado ainda mais expressivo se, como foi exemplificado, for observado o tipo de questão pontual que a matéria envolvia. Algo absolutamente cotidiano e distante de ser imaginado como causa de tensões políticas graves e que só ganha significado quando recebe tratamento quantitativo.

Sob essa classificação, estão agrupados procedimentos que se referem ao decorrer da vida profissional de um funcionário, tais como a dispensa de concurso; a nomeação; a inclusão ou o aproveitamento em certo cargo; a gratificação; a transferência; a equiparação de vencimentos; a contagem de tempo de serviço; a licença - sem ou com vencimentos ou ordenado; a aposentadoria - com todos os vencimentos ou com o ordenado; entre outros. Poucas dessas resoluções iam além do caso específico de um funcionário, possuindo um caráter mais geral.

As obras públicas, as posturas municipais e o transporte público ocuparam segundo, terceiro e quarto lugares das resoluções vetadas pelos prefeitos, respectivamente. Em se tratando das obras públicas - 29 vetadas, ou 12,55\% - grande parte das resoluções dizia respeito a algum tipo de intervenção nas ruas da cidade, havendo as que concediam ou prorrogavam o prazo estipulado para a abertura de ruas; as que autorizavam a aceitação de ruas abertas por particulares; as que mandavam efetuar o calçamento de ruas; as que concediam o direito de desapropriação por utilidade pública a particulares, para abrir ou prolongar ruas; as que mandavam construir bueiros; e, por fim, as que autorizavam a realização da limpeza e do embelezamento de certos espaços públicos.

Já as resoluções sobre posturas municipais — 27 vetadas, ou 11,69\% — diziam respeito, por exemplo, à localização dos depósitos de inflamáveis e de explosivos na cidade; à forma de enterramento nos cemitérios; à proibição de trabalho de menores de 16 anos em lugares de divertimentos públicos; ao Código de Polícia municipal; e, principalmente, a regras de construção e reconstrução de edifícios na cidade. Esse último caso correspondia a nada menos que dez das 27 resoluções vetadas, ou 37,03\%. Eram resoluções que, em sua maioria, criavam exceções ao regulamento geral de construção, como a que permitia construções independentes de licença e arruação em vários distritos, vetada por Francisco Furquim Werneck de Almeida, em 12 de setembro de $1895 .{ }^{15}$

No caso do transporte público, as medidas relacionadas à questão das linhas de bonde da cidade foram focos constantes de tensão. Para se ter uma ideia de sua dimensão, das 26 resoluções vetadas, apenas duas fugiam ao tema. Uma delas autorizava a abertura de concorrência para o serviço de barcas entre a capital federal e as ilhas de Paquetá e do Governador, e foi vetada por Henrique Valadares, em 22 de maio de $1894 .^{16}$

As outras 24 resoluções vetadas praticamente se dividiam em concessões para construção de linhas de bonde (oito resoluções) e autorizações para a revisão, a revogação de parte e a renovação de contratos firmados com companhias de ferro carril (nove resoluções). Isto é, as decisões sobre concessões e contratos firmados equivaliam a quase $71 \%$ das resoluções vetadas relacionadas ao transporte de bonde. Os outros $29 \%$ diziam respeito à alteração de tráfego nas linhas, à

14 Cf.: PINTO, Surama Conde Sá. Op. cit., p. 157.

15 Boletim da Intendência Municipal, de julho a setembro de 1895, p. 19.

16

Idem, de janeiro a junho de 1894, p. 54-55. 
elevação dos preços das passagens, entre outras.

O restante das resoluções vetadas - quase $30 \%$ do total - eram relativas à admissão de alunos, à dispensa de exames de ensino, à subvenção de escolas e à regulamentação do ensino municipal; à dispensa, à isenção, à criação, à redução e à prorrogação de pagamento de impostos; à abertura de créditos extraordinários e suplementares no orçamento municipal e o estorno entre rubricas do orçamento; ao abastecimento de carne verde; ao patrimônio municipal; à criação e à reorganização das repartições públicas; à concessão de extração de loterias; à atribuição de nome a um espaço público; e, por fim, à limpeza das casas particulares e do espaço público.

Feito todo esse balanço, cabe perguntar. De que maneira o tipo de matérias vetadas ajuda a compreender as relações entre os prefeitos e os intendentes do Distrito Federal? A separação por ano das matérias vetadas possibilita olhar com maior cuidado o período estudado.

Tabela 3

\begin{tabular}{|c|c|c|c|c|c|c|c|c|c|c|c|c|}
\hline Matérias & 1893 & 1894 & 1895 & 1896 & 1897 & 1898 & 1899 & 1900 & 1901 & 1902 & $\mathbf{T}$ & $\%$ \\
\hline $\begin{array}{l}\text { Funcionalismo } \\
\text { Municipal }\end{array}$ & 1 & 3 & 3 & 3 & 6 & 19 & 13 & 5 & 6 & 6 & 65 & 28,14 \\
\hline Obras Públicas & 7 & 2 & 2 & 2 & & 8 & 6 & & 1 & 1 & 29 & 12,55 \\
\hline $\begin{array}{l}\text { Posturas } \\
\text { Municipais }\end{array}$ & 3 & 2 & 4 & 4 & 1 & 1 & 7 & 3 & 1 & 1 & 27 & 11,69 \\
\hline $\begin{array}{l}\text { Transporte } \\
\text { Público }\end{array}$ & 1 & 1 & 4 & & 2 & 4 & 8 & 5 & & 1 & 26 & 11,26 \\
\hline $\begin{array}{l}\text { Ensino } \\
\text { Municipal }\end{array}$ & 1 & 1 & & & 1 & 4 & 3 & 1 & 2 & 1 & 14 & 6,06 \\
\hline Impostos & 2 & 2 & 1 & 1 & & & 1 & 2 & 2 & 1 & 12 & 5,19 \\
\hline Orçamentos & & & & & & 1 & 3 & 2 & 2 & & 8 & 3,46 \\
\hline Abastecimento & & & & 1 & 1 & 2 & & 1 & 1 & & 6 & 2,60 \\
\hline $\begin{array}{l}\text { Patrimônio } \\
\text { Municipal }\end{array}$ & & & & & 1 & 4 & 1 & & & & 6 & 2,60 \\
\hline $\begin{array}{l}\text { Administração } \\
\text { Pública }\end{array}$ & 1 & & & & & 2 & 1 & 1 & & & 5 & 2,16 \\
\hline Loteria & & & & 1 & 1 & 1 & & 1 & & 1 & 5 & 2,16 \\
\hline $\begin{array}{l}\text { Comemorações } \\
\text { e Homenagens }\end{array}$ & & & & & & 1 & 1 & 1 & & & 3 & 1,30 \\
\hline $\begin{array}{l}\text { Iluminação } \\
\text { Pública }\end{array}$ & & & & & 2 & 1 & & & & & 3 & 1,30 \\
\hline $\begin{array}{l}\text { Limpeza } \\
\text { Urbana }\end{array}$ & & & 1 & & & & 2 & & & & 3 & 1,30 \\
\hline $\begin{array}{l}\text { Desconhecidas } \\
\text { e Outras }\end{array}$ & & & & & 3 & 4 & 8 & 2 & 1 & 1 & 19 & 8,23 \\
\hline TOTAL & 16 & 11 & 15 & 12 & 18 & 52 & 54 & 24 & 16 & 13 & 231 & 100,00 \\
\hline
\end{tabular}

Natureza das matérias vetadas pelos prefeitos do Distrito Federal (1893-1902)

Fonte: Boletim da Intendência Municipal do Distrito Federal (1892-1902)

Logo se percebe que os anos de 1898 e 1899 foram os de mais alta concentração de vetos: 152 e 54 resoluções vetadas, respectivamente. O que equivale a $46 \%$ do total de resoluções vetadas entre 1893 e 1902. Para se ter dimensão da aceleração do ritmo de vetos interpostos, basta informar que o volume de resoluções vetadas em 1898 equivale a quase três vezes o ocorrido em 1897 que, até 15 
de novembro, correspondia à gestão de Werneck de Almeida.

Os anos de 1898 e 1899 foram justamente os de intensificação do processo de enquadramento político da capital federal, que visava, sobretudo, reduzir a atuação das forças políticas locais, por meio do enfraquecimento do Conselho e do fortalecimento do prefeito. O primeiro ano correspondeu ao final do governo de Prudente de Morais e o segundo ao início do governo Campos Sales. Como vimos, esse foi o período em que Ubaldino do Amaral e Cesário Alvim estavam à frente da prefeitura. No intervalo entre os dois prefeitos, por pouco mais de um mês, a gestão interina de Luiz Van Erven vetou 41,9\% das resoluções apresentadas para sanção, sinalizando, no que diz respeito aos vetos, uma relação bastante difícil com o Conselho. A gestão de Van Erven pode ser interpretada como uma prévia do que aconteceria na de Cesário Alvim.

A observação dos vetos por ano permite também perceber que somente a partir de 1898 é que as medidas que beneficiavam o funcionalismo passaram a estar sempre no primeiro lugar das resoluções vetadas. No caso, 49 dos 65 vetos (75,38\%) ocorreram entre 1898 e 1902. Nos anos restantes, excetuando 1894 e 1897, as prevalências de vetos referiam-se a medidas de intervenção em logradouro público (1893), no transporte público (1895) e nas posturas municipais (1895 e 1896).

Retornando às resoluções vetadas sobre as demandas do funcionalismo, vê-se que elas efetivamente se concentraram nos anos de 1898 e 1899, correspondendo a 32 dos 65 vetos, ou 49,23\%. Logo, tudo leva a crer que tais demandas eram as mais explosivas em se tratando das relações entre o Conselho e os prefeitos Amaral e Alvim.

Uma última variável que permite reunir mais pistas sobre as relações que existiram entre os prefeitos e o Conselho é a da distribuição dos decretos por instituição de sanção.

\section{Tabela 4}

Divisão dos decretos de acordo com o poder municipal que os sancionou (D.F., 1892-1902)

(Continua)

\begin{tabular}{|l|r|r|r|r|}
\hline \multicolumn{1}{|c|}{ Prefeito } & $\begin{array}{c}\text { N.o de } \\
\text { decretos }\end{array}$ & $\begin{array}{c}\text { Total por } \\
\text { mandato }\end{array}$ & $\begin{array}{c}\text { Sanções do } \\
\text { prefeito } \\
\%\end{array}$ & $\begin{array}{c}\text { Sanções do } \\
\text { Conselho } \\
\%\end{array}$ \\
\hline Henrique Valadares & 74 & & & \\
\hline Antônio Dias Ferreira* & 14 & & & \\
\hline João Baptista Maia de Lacerda* & 2 & & & \\
\hline & 238 & & & \\
\hline $\begin{array}{l}\text { Francisco Furquim Werneck de } \\
\text { Almeida }\end{array}$ & 44 & & & \\
\hline Joaquim Xavier da Silveira Junior* & 13 & & & \\
\hline Honório Gurgel** & 42 & & & \\
\hline Joaquim José da Rosa* & 4 & & & \\
\hline $\begin{array}{l}\text { Eugenio Guilherme de Magalhães } \\
\text { Carvalho** }\end{array}$ & & & & \\
\hline & 61 & & & \\
\hline Ubaldino do Amaral Fontoura & 39 & & & \\
\hline Joaquim José da Rosa* & 51 & & & \\
\hline Tertuliano da Gama Coelho* & 10 & & & \\
\hline Manoel Corrêa de Mello** & & 161 & 37,89 & \\
\hline
\end{tabular}


Tabela 4

Divisão dos decretos de acordo com o poder municipal que os sancionou (D.F., 1892-1902)

\begin{tabular}{|l|r|r|r|r|}
\hline \multicolumn{1}{|c|}{ Prefeito } & $\begin{array}{c}\text { N.․ de } \\
\text { decretos }\end{array}$ & $\begin{array}{c}\text { Total por } \\
\text { mandato }\end{array}$ & $\begin{array}{c}\text { Sanções do } \\
\text { prefeito } \\
\%\end{array}$ & $\begin{array}{c}\text { Sanções do } \\
\text { Conselho } \\
\%\end{array}$ \\
\hline José Cesário de Faria Alvim & 72 & & & 0 \\
\hline & & 72 & 100 & 0 \\
\hline João Felipe Pereira & 56 & & & 0 \\
\hline & & 56 & 100 & 0 \\
\hline Joaquim Xavier da Silveira Junior & 77 & & & 100 \\
\hline
\end{tabular}

Fonte: Boletim da Intendência Municipal do Distrito Federal (1892-1902)

* presidente do Conselho Municipal / ** vice-presidente do Conselho Municipal

O artigo 21 da Lei Orgânica de 1892 estabeleceu o prazo máximo de cinco dias para que o prefeito sancionasse ou opusesse veto por escrito a qualquer resolução aprovada pela maioria dos intendentes. Findo o prazo, caso o prefeito não se posicionasse, caberia ao presidente do Conselho o ato da sanção. Isto implica dizer que o legislativo municipal, na figura de seu presidente, também possuía a atribuição de transformar em lei uma resolução aprovada pelos intendentes. Porém, é extremamente importante frisar que o exercício de tal atribuição pelo presidente da casa legislativa dependia sempre da ação de abstenção do prefeito. Logo, o fato de se abster de sancionar ou de vetar uma resolução pode ser entendido como uma forma de delegar tal atribuição ao legislativo.

Na gestão de Werneck de Almeida, 103 das 341 resoluções foram sancionadas pelo presidente ou pelo vice-presidente do Conselho: $30,21 \%$. O ato de se abster da sanção ou da oposição de veto ocorreu, sobretudo, quando as resoluções visavam beneficiar o funcionalismo e intervir nos logradouros públicos, nas obras públicas. Nada menos que 58 das 103 resoluções (50,31\%) sancionadas pela casa legislativa versavam sobre tais temáticas. Isso pode ajudar a corroborar duas ideias: 1) a de que os temas do funcionalismo e da intervenção em logradouros são muito caros para o Conselho (por meio deles, os intendentes podem satisfazer os interesses de seus possíveis eleitores, travando uma aproximação maior com os habitantes da cidade); e 2) representam temas passíveis de barganha ou temas conciliadores, por meio dos quais o prefeito pode estreitar suas relações com o Conselho, permitindo que este decida sobre os temas que lhe são caros.

O prefeito Ubaldino do Amaral foi o que mais se absteve de sancionar ou vetar uma resolução aprovada pelo Conselho. Ao longo de sua administração, 62,11\% das resoluções foram sancionadas pela chefia do legislativo municipal, ou cem de 161, em números absolutos. Comparando com as gestões anteriores, esse prefeito se utilizou do recurso da abstenção quase quatro vezes mais do que Henrique Valadares e mais que o dobro de vezes que Werneck de Almeida. Com tais dados, é possível afirmar que, ao menos no que diz respeito à produção legislativa, o Conselho praticamente governou no período em que Ubaldino do Amaral esteve à frente da prefeitura.

Similar à gestão de Werneck de Almeida, as medidas relacionadas ao funcionalismo municipal e a obras públicas também ocuparam o primeiro lugar entre as resoluções sancionadas pela casa legislativa durante a administração de Ubaldino do Amaral, perfazendo o total de 41 entre cem resoluções. 
Pela divisão dos decretos de acordo com o poder municipal que os sancionou, percebi, no período, a existência de três situações básicas: a de prefeitos que não delegavam ao Poder Legislativo municipal a atribuição de sancionar resoluções; a de prefeitos que delegavam em parte tal atribuição; e, por fim, a de um prefeito que delegou a maior parte dessa atribuição ao Conselho.

$\mathrm{O}$ ato de delegar uma parcela das atribuições do Executivo para o Legislativo municipal podia significar uma tentativa, por parte dos prefeitos, de manter, minimamente, boas relações com os intendentes. Principalmente, se a abstenção fosse uma solução/alternativa encontrada pelos prefeitos para não interferir nas resoluções do Conselho, para vetá-las ou para sancioná-las. Com isso, dependendo da situação, os prefeitos terminavam por evitar a criação de impasses intransponíveis em suas relações com a casa legislativa.

É preciso lembrar que se abster podia também significar o inverso, ou seja, o aumento da tensão na relação entre o prefeito e o Conselho. Apenas como exemplo, vale o caso do prefeito Barata Ribeiro. Ele deixou passar o prazo de cinco dias para sancionar ou vetar uma resolução, ficando a cargo do presidente do Conselho desempenhar tal atribuição. Porém, ela possuía um prazo bastante específico para que fosse efetivada, e que era menor que os cinco dias legais para a sanção. Logo, ao deixar o prazo se esgotar, longe de evitar entrar em conflito com os intendentes, o prefeito não só vetou a resolução, que não mais se aplicava, como abriu uma crise com o Conselho. ${ }^{17}$

\section{O calcanhar de Aquiles das gestões municipais: o funcionalismo público}

O passo seguinte, visando compreender melhor as relações entre os intendentes e o prefeito, é acompanhar as justificativas utilizadas por Werneck de Almeida, Ubaldino do Amaral e Cesário Alvim para vetar resoluções, especialmente aquelas sobre o funcionalismo municipal que, como se demonstrou, são as que envolvem maiores tensões políticas.

A primeira gestão é a de Francisco Furquim Werneck de Almeida. ${ }^{18}$ Republicano histórico, em 1891 foi eleito como um dos representantes do Distrito Federal na Câmara dos Deputados, participando da Constituinte e da 1. ${ }^{\text {a }}$ Legislatura. Em março de 1894, foi reeleito deputado federal para a 2. ${ }^{\text {a }}$ Legislatura. Como deputado, participou da comissão responsável por elaborar um projeto acerca da organização municipal do Distrito Federal. Essa comissão era composta por sete deputados cariocas e possuía Tomas Delfino como relator. Ao longo de sua trajetória política, fez parte dos quadros do Partido Republicano da Capital Federal (PRCF), ao lado de políticos como Aristides Lobo e Tomas Delfino e, posteriormente, foi membro da seção carioca do Partido Republicano Federalista (PRF do DF), fundado em 1893.

Foi no período de domínio político do PRF que o presidente da República Prudente de Morais nomeou Werneck de Almeida. Aos 46 anos de idade, assumiu a Prefeitura do Distrito Federal, permanecendo no cargo de 1.을 de janeiro de 1895 a

17 Cf.: BASTOS, Ana Marta Rodrigues. Op. Cit., p. 79.

18 Nasceu em 29 de setembro de 1846, em Pati do Alferes, na então Província do Rio de Janeiro. Era filho de Francisco de Assis e Almeida - doutor em direito, proprietário de terras em Vassouras e deputado no Império - e Mariana Isabel de Lacerda e Almeida. Bacharelou-se em 1869 pela Faculdade de Medicina do Rio de Janeiro e exerceu a profissão de médico na cidade. Como parte de sua atividade profissional, tornou-se membro da Academia Nacional de Medicina. 
15 de novembro de 1897. Foi exonerado justamente por estar ligado politicamente a Francisco Glicério, liderança influente do PRF que entrou em rota de colisão contra o presidente Prudente de Morais, logo após o atentado de 1897.

Werneck de Almeida foi o primeiro prefeito pertencente às forças políticas cariocas. Seu partido - o PRF — possuía então a maioria das cadeiras do Conselho, o que ajuda a entender o baixo percentual de vetos interpostos pelo prefeito (10\%) e a razoável abstenção do ato de sancionar resoluções (30\%). Nesse aspecto, seu mandato é caracterizado por um amplo compartilhamento da responsabilidade de aprovar decretos entre Executivo e Legislativo municipal.

Outro indicativo das boas relações entre os poderes municipais pode ser encontrado nas razões dos vetos interpostos às resoluções sobre o funcionalismo. Das 38 resoluções vetadas, apenas nove diziam respeito a esse tema (23,68\%). Tais resoluções eram referentes à concessão de aposentadoria (duas), à inclusão no quadro de funcionários (três), ao preenchimento do lugar de professor catedrático (uma), à contagem de tempo de serviço (uma) e à reintegração de ex-funcionários (duas). O prefeito argumentou ter o Conselho invadido o raio de competência do Poder Executivo municipal, no que não podia concordar. As razões listadas para vetar nunca o colocavam numa situação de embate cerrado com os intendentes, o que aponta para um equilíbrio nas relações entre os dois poderes, e justamente no momento em que o regime republicano se iniciava.

Seu sucessor, Ubaldino do Amaral Fontoura nasceu na vila da Lapa, então pertencente à Província de São Paulo, no dia 27 de agosto de 1842. Bacharelou-se em 1867 pela Faculdade de Direito de São Paulo. Depois de formado, construiu uma carreira profissional de sucesso. Em 1874, transferiu-se para a cidade do Rio de Janeiro - então sede da Corte imperial — a convite de Saldanha Marinho, vindo a trabalhar em sua banca de advogado. Entre outras atividades, foi professor na Faculdade Livre de Direito do Rio de Janeiro e magistrado, chegando ao topo da carreira em dezembro de 1894, quando o presidente da República, Prudente de Morais, o nomeou Ministro do Supremo Tribunal Federal. Permaneceu no cargo por quase um ano e meio, sendo exonerado, a pedido, em 4 de maio de 1896.

Sua atividade legislativa é extensa, tendo sido eleito, em janeiro de 1891, senador pelo estado do Paraná. Durante a Constituinte, presidiu a Comissão dos 21, responsável pela revisão do projeto da Constituição. Em 30 de dezembro de 1891, renunciou à sua cadeira no Senado. Contudo, foi reeleito pelo mesmo estado em 15 de junho de 1892. Na Câmara Alta, exerceu os cargos de 1.ํㅗㄹ secrério e vice-presidente, entre maio de 1894 e maio de 1895.

Aos 55 anos de idade, e depois de ter saído do Supremo Tribunal Federal, assumiu a Prefeitura do Distrito Federal, nomeado por Prudente de Morais. Permaneceu no cargo por um ano — de 25 de novembro de 1897 a 15 de novembro de 1898 -, isto é, até o fim do mandato do presidente da República. Ubaldino do Amaral, portanto, assumiu o cargo num momento político conturbado, para o que o seu perfil de homem experiente e maduro muito deve ter contribuído. Ou seja, apenas 20 dias após o atentado à vida de Prudente de Morais, que vitimou o marechal Carlos Machado Bittencourt, ministro da Guerra, e no mesmo ano em que a República destruiu o arraial de Canudos.

Em 2 de março de 1898, na primeira mensagem proferida diante dos intendentes do Distrito Federal, como parte da cerimônia anual de abertura dos trabaIhos legislativos, Ubaldino do Amaral definiu claramente a conduta que adotaria enquanto estivesse à frente da prefeitura: 
[...] a ação do Prefeito há de se restringir às funções de obscuríssimo administrador, mais preocupado com o orçamento do que com a exibição de programa, tanto mais falaz mais perigoso, quanto mais brilhante. Cumpri-lhe resistir às pretensões individuais e partidárias, ainda com o risco de ver-se isolado, servindo de alvo a todos os ataques. ${ }^{19}$

Esse trecho sinaliza para a mudança ocorrida em relação à gestão anterior. No lugar de desempenhar uma função "política", Ubaldino se assumia como um "administrador", afastado de pretensões individuais e de programas partidários. Percebe-se que o prefeito atribuiu à sua forma de agir características absolutamente opostas às de Werneck de Almeida.

O ideal de política como boa administração é fundamental para se entender o fato de o prefeito ter, ao mesmo tempo, vetado de forma significativa e deixado o Conselho sancionar mais de $60 \%$ das resoluções aprovadas.

Ao se comparar a natureza das resoluções sancionadas pelo prefeito (61) e pelo presidente do Conselho Municipal (cem), logo se percebe não existir nenhuma matéria que tenha sido exclusiva de um dos poderes municipais. Isto é, ambos sancionaram resoluções sobre os mais diversos assuntos: orçamento, ensino municipal, posturas, administração pública, patrimônio municipal, limpeza urbana etc. Além disso, as resoluções que diziam respeito ao funcionalismo e à intervenção nos logradouros públicos — obras públicas — foram destaques nos trabalhos dos dois poderes.

O fato de o prefeito delegar ao presidente do Conselho Municipal a maior parte da atribuição de sancionar as resoluções aprovadas pelos intendentes podia significar, como já foi dito, uma tentativa de evitar um impasse instransponível com a casa legislativa. Porém, também podia indicar a transferência da responsabilidade sobre a sanção para o Legislativo, livrando-o do peso das críticas da opinião pública. Se levarmos em conta o discurso de Ubaldino do Amaral, defendendo o ideal da política como "administração", o sentido de transferir tal responsabilidade parece o mais verossímil. Logo, como administrador, supostamente distante de paixões e interesses, deixava para os intendentes não apenas a função de legislar, mas também, a de "governar".

No que diz respeito aos vetos, as resoluções sobre o funcionalismo municipal eram os alvos principais do prefeito Ubaldino do Amaral (17 dos 44 vetos, ou $38,64 \%) .{ }^{20}$ Nas resoluções vetadas, o prefeito sempre lançou mão da mesma justificativa, argumentando, sobretudo, que tais resoluções violavam os preceitos estabelecidos pela Lei Orgânica de 1892. Vejamos um caso.

Em 30 de novembro de 1897, o prefeito vetou a resolução que concedia um ano de licença, com todos os vencimentos, ao 2.․ำ ${ }^{\circ}$ icial do Arquivo Municipal, João Nepomuceno Bezerra Cavalcante, para tratar de sua saúde. ${ }^{21}$ Ubaldino do Amaral alegava que a resolução era contrária à Lei Orgânica, devido ao fato de o Conselho invadir as atribuições exclusivas do Poder Executivo municipal, atribuindo licença a um funcionário em particular. $\mathrm{O}$ argumento defendido era o de que a Lei Orgânica

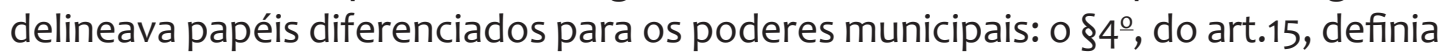
competir ao Conselho Municipal legislar, firmando regras gerais relativas ao fun-

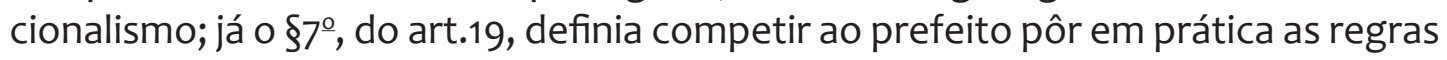

19 Mensagem do prefeito do Distrito Federal ao Conselho Municipal, 02/03/1898. Boletim da Intendência Municipal, janeiro a março de 1898, p. 47.

20 Cf.: Boletim da Intendência Municipal (1897-1898).

21 Boletim da Intendência Municipal, julho a dezembro de 1897, p. 118-119. 
gerais, nomeando, suspendendo, licenciando ou demitindo funcionários. Isto é, ao Conselho cabia desempenhar a função de legislar e ao prefeito a de administrar.

A justificativa de que o Conselho invadia as atribuições exclusivas do Executivo municipal foi utilizada também no momento em que Ubaldino vetou resoluções relativas à reintegração de ex-funcionários e à contagem de tempo de serviço. Nessa linha de argumentação, cabia ao prefeito mandar contar o tempo de serviço prestado pelo funcionário, por ser uma atribuição tipicamente administrativa. Ao reclamar da invasão das atribuições do Executivo municipal, Ubaldino do Amaral criticou o Conselho Municipal de forma indireta, lembrando-se das reclamações de seus antecessores:

Leis de exceção, de privilégio e monopólio, contra as quais muitas vezes reclamaram os meus antecessores, têm reduzido o Distrito Federal a uma situação que é para gerar cuidados e apreensões. Não desconheço o patriotismo e as retas intenções dos legisladores municipais, nem estranho que no tirocínio do sistema atual de governo se dêem vacilações e desvios.

Penso, porém, que cumpre velar incessantemente pela pureza das instituições. ${ }^{22}$

Ao analisar os motivos listados para justificar o veto interposto a cada uma das resoluções, percebi a presença do ideal de política como administração. O prefeito, quase invariavelmente, argumentava que o Conselho invadia as atribuições exclusivas do Executivo municipal. Nesse argumento, estava presente a perspectiva de caber ao prefeito o papel de administrador da municipalidade e aos intendentes o papel de elaboradores de leis.

A gestão de Ubaldino do Amaral parece marcada por uma relação bastante tensa com o Conselho Municipal. Os vetos das resoluções sobre o funcionalismo mostram, a todo o momento, uma efetiva disputa entre os poderes municipais, ao menos no que se refere à delimitação de competências e de atribuições.

Os embates com o legislativo municipal certamente se avolumaram na gestão de José Cesário de Faria Alvim..$^{23}$ Tanto no Império quanto na República, ocupou uma série de cargos no Executivo e no Legislativo. Membro do Partido Liberal, no Segundo Reinado foi eleito deputado provincial (1864-1866) e geral (1867-1868, 1877-1880, 1886-1889) por Minas Gerais. Republicano de última hora, participou do Governo Provisório, sendo Ministro da Justiça e do Interior, talvez por possuir fortes ligações com o marechal Deodoro da Fonseca. Em seguida, foi eleito senador, também por Minas, para participar dos trabalhos de elaboração da Constituição republicana. Renunciou à cadeira senatorial para assumir a primeira presidência constitucional do estado de Minas (18/06/1891-10/02/1892). Antes disso, já havia ocupado a chefia do estado de Minas (25/11/1889-10/02/1890) e sido presidente da Província do Rio de Janeiro (1884-1886).

Aos 59 anos de idade e com vasta experiência política, assumiu a Prefeitura do Distrito Federal, nomeado por seu colega de Governo Provisório, Campos Sales. Permaneceu no cargo de 31 de dezembro de 1898 a 31 de janeiro de 1900 e, após 13 meses de gestão, renunciou, devido a desavenças com o ministro da Justiça Epitácio Pessoa.

22 Ibidem, p. 119. Veto à resolução que mandava contar para todos os efeitos e pelo dobro o tempo de serviço militar em defesa do governo legal, prestado por José Rockert, escrivão da Agência da Candelária.

23 Filho do coronel José Cesário de Faria Alvim e de Thereza Januária Carneiro, nasceu em 7 de junho de 1839, no povoado de Pinheiro, município de Piranga, na então Província de Minas Gerais. Bacharelou-se, em 1862, pela Faculdade de Direito de São Paulo. 
Cesário Alvim chegou à prefeitura num momento em que a partilha de poder estabelecida pela Lei Orgânica de 1892 sofria, ao menos no âmbito legal, modificação significativa. Oito dias antes, o presidente da República Campos Sales sancionou o Decreto $n .{ }^{\circ} 543$, que restringia as atribuições do Conselho Municipal e aumentava tanto o poder do prefeito como o controle deste por parte do Executivo federal.

Em se tratando da restrição de atribuições, o decreto constituiu-se num duro golpe para os intendentes. $\mathrm{O}$ art. $9 .^{\circ}$ definia competir exclusivamente ao prefeito a "iniciativa da despesa, bem como a da criação dos empregos municipais e do recurso a empréstimos e operações de crédito". Essa mudança retirava dos intendentes uma das principais moedas que ajudavam na manutenção de suas redes de influência. Sem poder criar empregos e despesas, teriam que encontrar formas alternativas para responder às demandas de seus representados. Além disso, o Conselho também perdeu a atribuição de avaliar uma parte dos vetos opostos pelo prefeito, o que voltava a ser uma competência exclusiva do Senado Federal. Logo, a gestão de Cesário Alvim foi a primeira a ensaiar o novo experimento político pelo qual passavam os poderes municipais. Experimento que tentava fortalecer a figura do prefeito em detrimento do Conselho.

Os dados quantitativos analisados até aqui mostram que a gestão de Cesário Alvim na prefeitura foi marcada por uma relação bastante conflituosa com o Conselho, tendo o prefeito vetado mais de $40 \%$ das resoluções apresentadas para a sanção. Ao longo de sua gestão, as resoluções que diziam respeito a medidas que beneficiavam o funcionalismo municipal também foram as mais vetadas (13 dos 55 vetos, ou $23,64 \%) .{ }^{24}$

As 13 resoluções vetadas referentes ao funcionalismo não apresentam nenhuma concentração significativa sobre um determinado assunto, sendo relativas à reintegração de ex-funcionário (três), a vencimentos (duas), à concessão de licença (duas), a aproveitamento em determinado cargo (duas), ao montepio (duas), à equiparação entre cargos (uma) e à indenização (uma). Quanto às razões dos vetos apresentadas por Cesário Alvim, elas eram, na maioria das vezes, similares às utilizadas por Ubaldino do Amaral, sendo a acusação de invasão da área de competência do prefeito central em oito dos 13 vetos.

Como as duas resoluções sobre vencimentos geraram uma imensa disputa de poder, envolvendo o prefeito Cesário Alvim e os membros do Conselho, só solucionada depois de muitos ataques de ambos os lados, com a decisão oficial dos senadores, é importante acompanhar o caso mais de perto, mais detidamente.

Em 6 de março de 1899, Cesário Alvim vetou a Indicação do Conselho contrária à redução de $10 \%$ nos vencimentos do funcionalismo. ${ }^{25} \mathrm{Na}$ justificativa do veto, dirigida aos senadores, o prefeito fez um breve histórico acerca do que o levou a promulgar o Decreto n.․ 123 , de 27 de janeiro de 1899 , que reduziu em $10 \%$ os vencimentos do funcionalismo.

Ao ocupar a chefia da prefeitura, afirmou ter encontrado a municipalidade numa precária situação financeira, com contas a pagar vencidas, obras paradas, condenações judiciárias, fama de devedora e três meses de vencimentos atrasados do funcionalismo. Para reverter essa situação, elaborou um programa de severa economia, que o credenciou a conseguir um empréstimo vantajoso no Banco da República. Programa que tinha como ponto central atacar o problema de excesso de funcionários, diagnosticado pelo prefeito como sendo a causa do desequilíbrio

24 Boletim da Intendência Municipal do Distrito Federal (1898-1900).

25 Cf. o teor da Indicação do Conselho em: Boletim da Intendência Municipal, janeiro a março de 1899, p. 90. 
financeiro, já que o pagamento dos vencimentos consumia quase $2 / 3$ da receita da municipalidade. Por tudo isso, estabeleceu, como ato do Poder Executivo, a contribuição de $10 \%$ nos vencimentos dos funcionários, condicionando a sua suspensão no orçamento de 1900 ao fato de conseguir folga de recursos e restabelecimento de crédito.

Feito o histórico dos motivos para promulgar o Decreto n. ${ }^{123}$, o prefeito não perdeu a oportunidade de acusar o Conselho de falta de colaboração para reverter a precária situação financeira da municipalidade, preferindo ficar do lado fácil da defesa dos funcionários:

E em tais circunstâncias que o Conselho profere, como a primeira palavra de sua colaboração, que espero, será mais tarde fecunda em bens para o município, a presente indicação revogatória dos atos do Prefeito em matéria de tanta magnitude! ${ }^{26}$

Cesário Alvim defendeu que seu ato estava baseado na autorização, concedida pelo próprio Conselho, de reorganizar as repartições públicas, reduzindo o pessoal e suprimindo os lugares dispensáveis. Como o fim último dessa autorização era o de conter as despesas municipais, sendo a reorganização um processo moroso, de resultados a longo prazo, decidiu-se por reduzir os vencimentos dos funcionários, já que reverter a situação financeira era algo inadiável.

Por fim, depois de levantar a questão da competência do Conselho quanto à criação de despesa, concluiu a justificativa do veto à indicação, fazendo uma crítica muito ácida aos intendentes, acusando-os de agir em favor de seus próprios interesses, ao invés dos interesses gerais. ${ }^{27}$

Os 10\% de redução nos vencimentos do funcionalismo voltaram a ser discutidos no Conselho em 6 de setembro de 1899, cinco dias depois de o prefeito apresentar a proposta orçamentária de 1900, sem fazer menção de suspender a redução. Na sessão ordinária, o intendente Leite Ribeiro, o mesmo responsável pela formulação da indicação vetada em março por Alvim, apresentou o projeto de lei n.․ 108, que anulava o Decreto $\mathrm{n} . .0123$, de 27 de janeiro de 1899 .

Antes de iniciar o trâmite legislativo o projeto já possuía o apoio da maioria dos intendentes, tendo sido assinado por mais sete membros da casa. ${ }^{28}$ Tal grau de apoio sinalizava o quanto essa questão era cara ao Conselho, algo que foi ressaltado por Leite Ribeiro em seu discurso de apresentação do projeto:

[...] o Conselho Municipal não pode ficar indiferente à questão dos $10 \%$. Julga preciso terminar de vez essa causa, na qual estão comprometidos os interesses dos funcionários; já não fala do interesse dos Intendentes, interesse moral, bem entendido, pelo desprestígio que nessa questão tem sofrido o Conselho. ${ }^{29}$

Aceito pela Mesa do Conselho, o projeto foi encaminhado para entrar na ordem dos trabalhos. Aprovado sem debates em primeira e em segunda discussão, somente na terceira, quando Leite Ribeiro fez um histórico da questão, houve um forte embate com o prefeito.

26 Ibidem, p. 90.

27 Cf.: Ibidem, p. 91.

28 Antônio José Leite Borges, Figueiredo Rocha, Manoel Rodrigues Alves, Mattos Rodrigues, Pereira Braga, Numa Vieira e Leôncio de Albuquerque.

29 Anais do Conselho Municipal, 2. e sessão ordinária de 01/09 a 30/10/1899, p. 54. 
Em 27 de janeiro de 1899, aproveitando-se do recesso do legislativo municipal, o prefeito Cesário Alvim decretou um ato que reduzia em $10 \%$ os vencimentos do funcionalismo. O texto do decreto trazia a ressalva de que o ato seria submetido à futura deliberação do Conselho. Antes de decidir apresentar uma indicação, Leite Ribeiro pensou em falar diretamente com o prefeito, para tentar convencê-lo de suspender a redução dos vencimentos, porém, desistiu de tomar tal atitude. Segundo ele mesmo:

\footnotetext{
O orador se achava disposto, nessa ocasião, a ir ao gabinete do Sr. Prefeito fazer-lhe ver que o Conselho não poderia, sem quebra de dignidade, aprovar aquele ato. Quando, porém, ouviu a leitura da Mensagem inaugural de S. Ex., o orador se sentiu inibido de levar a efeito aquela sua resolução diante dos termos da aludida Mensagem que parecia querer dar ao Conselho lições de honestidade. ${ }^{30}$
}

Com isso, em 2 de março de 1899, em vez de ir ao prefeito, apresentou uma indicação, aprovada pela maioria dos intendentes, que declarava sem efeito o ato do Poder Executivo municipal. Em 6 de março, obviamente, a indicação foi vetada pelo prefeito. As razões apresentadas por Cesário Alvim agravaram ainda mais a relação com o Conselho. O Senado Federal devolveu o veto para o prefeito, alegando não poder se posicionar, pelo fato de se tratar de uma indicação em vez de uma resolução. Porém, alguns senadores deram sinais de que consideravam ilegal o ato do prefeito. Logo, para obrigar o Senado a se posicionar, Leite Ribeiro decidiu transformar a indicação num projeto de lei. No encerramento de seu discurso, qualificou a ação do prefeito como ditatorial: "O que o orador não pode é deixar passar sem um veemente protesto o ato ditatorial do Poder Executivo, ato esse que atenta contra a dignidade do Poder Legislativo Municipal". ${ }^{11}$ Em seguida, o projeto foi aprovado por maioria absoluta de votos dos intendentes.

Em 15 de setembro de 1899, adicionando mais um capítulo ao impasse com o Conselho, o prefeito Alvim vetou a resolução que anulava o Decreto n.․1ㅡ. Nas razões do veto, argumentou que faltava competência ao Conselho para anular os atos do Executivo municipal, expedidos no uso legal de suas atribuições: "Assim procedendo, arvora-se em Juiz supremo do Prefeito, que não lhe é subordinado; e, a vigorar semelhante doutrina tornar-se-ia o Conselho o único poder administrativo do Distrito, convertendo-se o Prefeito em seu Delegado". ${ }^{32}$

O prefeito argumentou que não havia, em nenhuma das leis de organização do Distrito Federal, a autorização - conferida ao Poder Legislativo municipal de invalidar qualquer ato do prefeito, mesmo pressupondo ser contrário às leis em vigor. Na dúvida sobre a legalidade de qualquer ato do prefeito, defendeu caber ao Judiciário, em vez do Conselho, o papel de julgar a questão.

Chegando o veto ao Senado, foi encaminhado aos membros da Comissão de Constituição, Poderes e Diplomacia para interpor parecer. Na sessão de 21 de setembro de 1899, foi apresentado o parecer da comissão, propondo a rejeição do veto, assinado pelos senadores Vicente Machado e Pedro Velho. A tônica presente no parecer era a de que o Executivo municipal invadiu as atribuições do Conselho, ao se achar competente para legislar. ${ }^{33}$

30 Ibidem, p. 70.

31 Ibidem, p. 71.

32 Boletim da Intendência Municipal, de julho a setembro de 1899, p. 21.

33 Cf.: Anais do Senado Federal, sessão em 21 de setembro de 1899, p. 191. 
Por se tratar de um assunto já conhecido pela Casa, desde o envio da indicação vetada pelo prefeito, um membro da comissão, o senador Vicente Machado, requereu que o parecer fosse dado para a Ordem do Dia seguinte, sem a necessidade de aguardar a publicação em avulso. Aprovado o requerimento, o parecer entrou na Ordem do Dia da sessão de 22 de setembro de 1899. Após uma breve tentativa infrutífera de adiar a discussão, feita pelo senador Domingos Vicente, começou o debate, que foi polarizado pelos senadores Coelho e Campos e Vicente Machado.

A discussão entre os senadores circulou em torno da questão do Conselho ter ou não competência para anular um ato do prefeito considerado ilegal, devido ao fato de invadir atribuição exclusiva do próprio legislativo municipal. A posição defendida pelo parecer da Comissão de Constituição, Poderes e Diplomacia foi vitoriosa no Senado, reconhecendo o direito do Conselho. Por 35 votos contra seis a favor do parecer, o veto do prefeito foi rejeitado pelos senadores.

Passados sete meses de conflito entre os intendentes e o prefeito, com trocas de acusações de ambos os lados e com atribuições de qualificativos nada amistosos, o Conselho Municipal — que se posicionou a favor do funcionalismo — saiu vitorioso, conseguindo a sanção do Decreto n. 706 , de 25 de setembro de 1899 , que declarava nulo, para todos os efeitos, o Decreto n.․123, de 27 de janeiro de 1899 .

Ao longo do tempo, como uma das soluções para a obtenção de um equilíbrio financeiro do Distrito Federal, os prefeitos, numa espécie de consenso, começaram a defender as necessidades de reduzir os benefícios atribuídos aos funcionários públicos, de diminuir o próprio número de funcionários e, também, de reorganizar as repartições municipais, no sentido de torná-las mais modestas e econômicas. Dentre os que ocuparam o cargo de Prefeito, Barata Ribeiro foi uma voz dissonante, pelo fato de propor, ao invés da redução, o aumento do número de funcionários. Qual era o lugar de Ribeiro na municipalidade? Por que essa diferença em relação aos seus sucessores?

Em 1. de março de 1893, Cândido Barata Ribeiro proferiu sua primeira mensagem ao Conselho, que acabaria sendo também a última, pois deixou o cargo em 25 de maio de 1893, logo após a rejeição de sua indicação pelos membros do Senado. Na mensagem, argumentou que, devido à implantação da Lei Orgânica, a administração municipal passava por um período de transição. Isto é, o ConseIho de Intendência, instituição provisória criada em 1889 e que perdurou até 1892, estava sendo substituído pelos poderes Executivo e Legislativo municipais. Por isso, a lei transferiu diversas atribuições que eram da competência da União para a municipalidade.

O alargamento do raio de ação da municipalidade - que o prefeito diagnosticava como crescente desde 1889, quando se extinguiu a Câmara Municipal do Império - foi uma das justificativas para não apresentar aos intendentes a proposta orçamentária de 1893. Outra razão dizia respeito ao argumento de ser a proposta orçamentária dependente tanto das receitas quanto das despesas que estavam sendo criadas pelos membros do Conselho Municipal. Os dois argumentos reforçavam a ideia de que não adiantava a prefeitura apresentar uma proposta orçamentária, tomando como base os valores monetários gastos no ano anterior, quando a administração municipal era desempenhada pelo Conselho de Intendência e possuía um número muito menor de atribuições.

A partir do princípio de que a municipalidade passava por um período de transição institucional, Barata Ribeiro apresentou dois problemas a serem enfrentados pelo Conselho Municipal: o de organizar as repartições municipais de acordo 
com as necessidades dos novos serviços e o de suprir a municipalidade com novos funcionários. Com relação à falta de pessoal, o prefeito citou como exemplo a situação da Diretoria de Obras, em que cada funcionário ficava responsável por dar andamento a dezenas de processos.

A mensagem inaugural de Barata Ribeiro ajuda a colocar em perspectiva o calcanhar de Aquiles das demais gestões municipais. Em pouco tempo de organização municipal aos moldes da Lei Orgânica de 1892, a questão do funcionalismo sofreu uma inflexão, deixando de incomodar pela falta e passando a incomodar pela presença, altamente detectada nas gestões de Ubaldino do Amaral Fontoura e José Cesário de Faria Alvim. As mensagens dos prefeitos posteriores a Barata Ribeiro atribuíam ao significativo número de funcionários parte dos males financeiros enfrentados pela municipalidade. Logo, em apenas uma década, de 1892 a 1902, os funcionários municipais passaram de solução a problema, o que colocava em guerra o prefeito e os intendentes. A análise minuciosa dos vetos é um caminho para entender as tensões e conciliações na política municipal.

Recebido em 16/05/2013

Aprovado em 10/06/2013 